\title{
A MONASTIC STAR TIME TABLE OF THE ELEVENTH CENTURY.
}

THE text printed below is taken from Bodley MS 38 (8849), and covers nine small ${ }^{2}$ vellum pages, fol. $19 b$ to $23 b$. It deals with the appearance in the sky, and in relation to the buildings of a monastery, of certain constellations, and the observations were taken by a monk to enable him to know the hour, at which on certain holy days, to begin, or to prepare for, the office of the night. They appear to be based upon, or suggested by, the treatise by Gregory of Tours entitled De Cursu Stellarum Ratio, ${ }^{2}$ and the monk uses as guides several of the stars chosen by Gregory. The notes have no formal beginning; they follow on the same page the last of a series of six liturgical cantica, chiefly tropes of various sorts, written by the same hand, and put together apparently at haphazard. Probably the collection was intended merely for the monks' private use.

It has proved beyond my power to identify the monastery where the o bservations were made; and there are at once too many and too few indications of locality to allow of a satisfactory conjecture. The following facts offer all the evidence available:-

(I) The manuscript is written in a hand of about the middle of the eleventh century.

(2) It was written in a Benedictine bouse ${ }^{3}$ in France.

(3) On the south of the church was the cloister with the dormitory on the east side, the refectory on the south, a closet, armarium, making the corner between. The dormitory had seven windows, and the refectory four, which the observer counted from left to right." He stood apparently in the open air of the cloister garth. He had an appointed place, but moved from it to take certain observations.

(4) A church of S. Aignan-or possibly an apsidal chapel on the south of the choir of the monastery church-rose above the north end of the dormitory roof. From one place in the cloister could be seen the writing over S. Aignan's altar..$^{\mathrm{s}}$

$14 \frac{1}{4} \times 2 \frac{3}{4}$ inches.

2 Printed in Monumenta Gemaniae Historica, Seriptorum Rerum Merovingicarum i p. 854 My attention was drawn to this connexion by my friend Miss Rose Graham, to whom I owe my best thanks for some help also in the completion of this paper.

a See the observation for March 2 I.

- The orientation of the monastery church was probably not due east and west, but a little north-east and south-west.

5 Cf. 'Iuxta parietem Sancti Aniani . . super seripturam altaris Sancti Aniani'. 
(5) There was a chapel of All Saints visible over the south or southeast side of the cloister.

(6) The last of the cantica referred to above celebrates S. Nazarius as one who huic patriae procuravit inluminatorem.'

(7) The manuscript was at one time the property of Peter Daniel, the sixteenth-century Orleans collector and bailli of Fleury, and the volume, in what appears to be contemporary binding, bears his name.

The clue to the whereabouts of the monastery-which it will be observed was of the most usual plan-would seem to lie in the connexion of the volume with Peter Daniel, and further in the bringing together in the notes of the saints whose worship was not common to every French diocese, viz. S. Aignan, S. Nazaire, and two others whose festivals are mentioned, S. Launomar or Lomer and S. Germanus of Auxerre.

The late Librarian of the Bodleian, Mr E. W. B. Nicholson, left S. Nazarius out of the account, and decided that the manuscript was almost certainly written at Orleans in the Benedictine monastery of S. Aignan. ${ }^{2}$

This opinion is open to question on two grounds. (I) Was the house of S. Aignan a Benedictine monastery in the eleventh century? (2) Do the local conditions suit the requirements of the MS? With regard to the first point it is hard to give a perfectly satisfactory answer, as the archives of S. Aignan's were burnt in $1562,{ }^{3}$ and were reconstructed by the chapter from any available sources that were to be found. The new documents may have been made, it may well be argued, under the influence of the owners of that day who were unquestionably a chapter of canons. But the verdict of all the historians' of S. Aignan's and of Orleans is unanimous as to the unbroken tenure of the church by canons from the middle of the ninth century down to 1790 . And it is scarcely possible that so important a church could pass in the eleventh century from the hands of canons

\footnotetext{
- The five other cantica afford no clue to identification. I owe this observation to my friend the Rev. H. M. Bannister.

2 Madan, Summary Catalogue of Western MSS in the Bodleian Library, Nos. 1667024330, App. p. 730. Notes by E. W. B. Nicholson.

- Memoires de la Societe archtologique de l'Orleanais vol. iv p. 80.

- Hubert, Antiquites historiques de D' Elise royale de St-Aignan d'Orleans, I have not consulted, there being no copy in Oxford, in the British Museum, or in the Cambridge University Library; but references to Hubert by other writers are unmistakeable. See also Saussaye, Annales Ecclesiae Auvelianensts. Lemaire, Histoire et Antiquites de la Ville at Duche d'Orleans. E. Bimbinet, and ather writers in Mém. de la Soc. arch. de IOrleanais, vols. 4, 9, 11, 18, 21 . The charter printed by PflugkHarttung, as belonging to S. Aignan at Orleans, ann. I061, refers to the monastery of S. Benoit d'Aniane, Acta Ponlificum Romanorum inedita iii 9.
} 
into those of monks and be restored to the canons without some reference to the transaction remaining in some document or chronicle. Gallia Christiana claims for S. Aignan's a Benedictine origin, but in an agreement about a burial-ground, dated 854 , between Agius bishop of Orleans ${ }^{1}$ and the owners of S. Aignan's, they are called canons. ${ }^{2}$ In 999 the church was burnt down, and was rebuilt by Robert the Pious. The ceremony of restoring the reliques of S. Aignan to their place in the new church took place in ro29. Helgaldus, the biographer of King Robert, gives a full description ${ }^{3}$ of the building, and of the translation. He uses the word monasterium to denote the church itself. Nineteen altars to saints are mentioned by him, of whom no less than nine including $\mathrm{S}$. Benedict correspond with those named by the monk of the star-notes. Helgaldus does not refer to any capitular buildings, nor does he indicate in any way the order by which the church was to be served. This omission, it may be noticed, would be the more natural if the chapter of canons which had held it till its destruction in 999 resumed possession in 1029. The interval for the rebuilding of a great church was indeed short enough ${ }^{4}$ to allow of at least some of the dishoused canons assisting at the consecration of the new building. The abbots of S. Aignan were commonly great political personages, but the list of deans is given complete in Gallia Christiana. The fact that several of the early deans held at the same time offices ${ }^{5}$ in the Chapter of the Canons of the Cathedral Church of $\mathbf{S}$. Cross confirms the presumption that at the date of the MS under consideration the church of S. Aignan was not Benedictine.

The second objection to accepting Mr Nicholson's view as to the monastery where the star-notes were written rests upon the local position of the church of S. Aignan at Orleans. The church completed in ro29 was destroyed in 1370 , but the crypt $^{6}$ has been decided by careful investigation to remain practically perfect. It is built upon the north bank of the Loire where the ground falls away somewhat sharply to the river. The

1 Reproduced in the Mimoires de la Societé des Antiquaires de France for $\mathrm{t} 866$, ix, 3rd series 'Ego Agius episcopus venerabilium canonicorum monasterii Sancti Aniani'. Also in $\mathrm{Mem}$. arch. de l'Orl. xi p. 483 .

2 See also Gall. Christ. vii ${ }^{1521}$ '... Caroli Crassi quo tempore Sancti Aniani monasterium seculari toga iam erat donatum'.

- Recueil des historiens des Gaules et de la France $x$ I I I.

- The next rebuilding begun by Louis XI took 70 years, Buzonnière Histoire architecturale de la ville d'Orléans i $3 \mathbf{I} 3$.

- Tedelinus, dean in 1029, was sub-dean of S. Cross. Robert, dean in 1038, was canon of S. Cross. Stephen de Garlande was dean of S. Samson in I 108, S. Aignan in Ir11, S. Cross in 1113 , and returned to S. Aignan in 1114. Gall. Christ. viii 1522.

- Buzonnière Histoire architecturale i 298. 
floor of the present fifteenth-century church, says Monsieur Buzonnière, though on the north level with the ground outside, is on the south relativement exhausst de quatre mitres et plus. ${ }^{1}$ The fall of the earth was perhaps less in 1029, but at no time could the situation have been favourable for the buildings of an important abbey. No trace of eleventh-century constructions have been found south of the crypt. ${ }^{2}$ Charles VIII gave leave to the chapter to raise 30,000 livres from the octroi of the city to complete a small south cloister ${ }^{3}$ which probably led to the sacristy and chapter-house. But the canons' entrance was on the north." There was no access to the church up the bank of the river, and so much was this aspect shut off that the architect of the present church completely neglected the external decoration of that side of his building. ${ }^{5}$ In fact not only do no traces survive of a spacious dormitory and refectory on the south of S. Aignan's, but it seems probable that neither in the eleventh cantury nor later was there any provision made near the church for the residence of its chapter.

If, however, we dismiss Mr Nicholson's identification, I have found it impossible to make a satisfactory suggestion in its place. Peter Daniel collected books from many places besides Fleury. At Fleury itself no record remains of there ever having been a chapel to S. Aignan, or a church dedicated to that saint, in close neighbourhood to the monastery, nor a chapel ${ }^{7}$ of All Saints in the monastery grounds, or on the walls. Moreover some saints specially connected with Fleury are absent from the monk's calendar. The list indeed has baffling omissions. The day of the dedication of the church and of the patron saint are not mentioned. There are also breaks in the continuity of the observations; one long interval from March 21 to June 24 includes the time of the great moveable feasts; and several shorter ones occur of from four to six weeks' duration. It is probable that the same monk did not do all the watching throughout the year, and it is unlucky for my purpose that the time of his supposed absence corresponds with the dates of S. Nazarius, June 12, S. Aignan, Bishop of Chartres, June 10, and the day of the deliverance of his city by S. Aignan of Orleans, June I 4. On the other hand, had S. Aignan, as Mr Nicholson assumed, been the patron saint of the monastery, one would expect to find his

1 Buzonniere Hist. arch, i 323.

2 Ibid. i zoz.

3 Ibid. i 312, 314 .

- Ibid. i 313.

s Ibid. i 313, 319.

- There was an altar to S. Aignan at a.later period, and the 19 th of December was a festival in the church in connexion with it. Rocher History of S. Benoit-surLoire p. 326.

7 There were two chapels in the precincts of the monastery, dedicated to S. Pettr and to S. Lazarus. The great church was burnt down in 1026 and onily rebuilt in 1071 . 
other festival on November I 7 commemorated, for the monk duly makes his observation for All Saints' Day and for S. Clement on November 23. The manner, however, in which S. Aignan is referred to in the text makes it extremely unlikely that he held the place $\mathrm{Mr}$ Nicholson assigned him. In the service books that $\mathrm{I}$ have consulted giving the order of service on special festivals, processions, and so forth, the monastic church is referred to as ecclesia ${ }^{1}$ simply. If the reference to S. Aignan indicates a separate church, we must suppose the monk's monastery to be in a town, or to have a parish, or second monastic, church within its boundaries. But it seems unlikely that a mere parish or secondary church would be so lofty as to dominate the cloister and dormitory.

Chartres with its Church of S. Aignan, rising on a fairly steep hill above the great convent of $S$. Père, might possibly be the home of the star-watching monk. But the cloister of S. Père appears to lie a little too much to the east, and I have not been able to trace any chapel of All Saints in the town. Moreover, the absence of saints in the monk's calendar should be considered as well as their presence, and at Chartres one would expect to find S. Lubin commemorated on March $\mathrm{I}_{3}$, and a monk of S. Pere to give special honour to the festivals of S. Peter, so closely associated with his house. Two of the less usual saints mentioned in the MS, S. Aignan and S. Nazaire, are found honoured in the diocese of Narbonne. And the twin monasteries of S. Laurent and S. Aignan-called together S. Chinian-suggest themselves as a tempting solution of the problem. But here again certainty is unattainable, and the data recoverable is insufficient for even a conjectural identification.

With regard to the question of the hours on the different days at which the monk roused the convent it is impossible to reach a definite conclusion, since the exact geographical position of the monastery, the orientation of the church, the height of the buildings, and the precise date of the observations are all unknown to us. But it would seem that the services to be attended belong to three classes of festivals lasting more or less time before cockcrow. The approximate results of calculations for the year $1100^{2}$ of the position of the stars on the days mentioned can be tabulated as follows:-

Dec. 25, Christmas, evening.

Jan. 1, Circumcision, midnight.

Jan. 19, S. Launomar, 2 a.m.

Jan. 20, S. Sebastian, midnight.

1 Except of course where the name of another church has been introduced into the order of ceremonial.

I owe the astronomical notes and calculations to the kindness of Mr E. B. Knobel, Fellow, and twice President, of the Royal Astronomical Society. 
Jan. 2 r, S. Agnes, 2 a.m.

Jan. 22, S. Vincent, midnight.

Jan. 25, Conversion of S. Paul, 2 a.m.

Feb. 2, Purification, midnight.

March 2 I, Translation of S. Benedict, evening.

June 24, S. John the Baptist, evening.

June 29, SS. Peter and Paul, evening.

July 3r, S. Germanus of Auxerre, evening.

Aug. 3, S. Stephen, midnight.

Sept. 2 I, S. Matthew, midnight.

Sept. 29, S. Michael, midnight.

Sept. 30, S. Jerome, midnight.

Oct. I, S. Remigius, midnight.

Oct. 28, SS. Simon and Jude, 2 a.m.

Nov. I, All Saints, evening.

Nov. 23 , S. Clement, 2 a.m.

On most of the nights of his watching the monk leaves his actual duties unrecorded. He has to ring the bell on Christmas evening, and on the festivals of S. Germanus and All Saints. On the latter night and on the Circumcision he kindles the lamps. But his last words 'Prepare thyself to rouse the Brethren ' are probably meant to cover the directions for the whole year.

- Rachael Poole.

Bodl. MS 38 Bernard (8849).

l. 19 b] In natale domini [Dec. 25] cum geminos quasi super dormitorium iacentes uideris et signum ORIONIs - super capellam omnium Sanctorum preparate ad commouenda signa. In CIRCUMCISIONE domini [Jan. I]

[20 a] dum claram stellam quae in / genu ARTOPHILACIS est - contra spatium quod inter primam et secundam dormitorii fenestram habetur quasi super summum tectum uideris tunc ad accendendas lucernas perge.

In Sancti Launomari [Jan. I9] et sanctae AGnetis [Jan. 21] dum lances quas VIRGo dicitur tenere duas uidelicet claras stellas contra spatium quod est inter sextam et septimam dormitorii fenestram alcius

[20 b] eleuatas aspexeris. Similiter \& in conversione | Sancti Pauli. [Jan. 25] Ast in Sancti Sebastiani [Jan. 20] dum easdem stellas contra spatium quintę et sextę fenestrę uideris - ita tamen ut uiciniores sint sextę. Verum in Sancti VincenrII [Jan. 22] dum super quintam fenestram uicinas tecto \& quasi surgentes uideris \& hoc adtende - ut ad contem. plandas eas a designato loco paululum retro uersus sauinam. ${ }^{1}$ per uiam putei secedas - ut fenestras et uidere et numerare possis. 1

1 Can this mean 'a juniper bush'? 
In Purificatione Sanctae Mariz̨ [Feb. 2] dum stellam quę in genu [21 a] artophilacis est in[ter] terciam ${ }^{2}$ et quartam dormitorii fenestram uideris . ita tamen ut uicinior uideatur tercię quam quartę.

In transitu Sancti Patris Benedicrı xij uidelicet K. April. [Mar. 2 r] dum contra sextam dormitorii fenestram - lances quasi alte positas uideris uel stellam de genu. Artophylacis - contra medium spatium quod est in [ter] terciam et quartam dormitorii fenestram. | Is festiuitate Sancti [a b] iohannis precursoris domini [June 24] dum signum Sagittae contra spatium quod est inter quintam et sextam dormitorii fenestram uideris . ita tamen ut uicinius sit quintę quam sextę seu cum caput equi contra secundam dormitorii fenestram quasi tecto super iacentem uideris. In festiuitate sanctorum Petri et Pauli - [June 29] quando ipsum caput quasi uicinum tercię dormitorii fenestre uideris - \& signum Sagittę. In [22a] Kalendis | Augusti [Aug. r] \& in festiuitate Sancti German I [July 3 I ] quę eas precedit dum uideris signum Sagitte contra spatium quod est in[ter] terciam et quartam Refectorii fenestram certo loco iuxta polum scilicet constitutus atque ad meridiem conuersus - tunc ad commouendum signum nocturnalium ymnorum te prepara. Is translatione Sancti Stephani [Aug. 3] dum eam inter primam et secundam uideris. IN festiuitate Sancti Mathei [Sept. 2I] conuersus ad orientem | dum contra primam [22 b] dormitorii fenestram quę est iuxta parietem Sancti Aniani duas geminorum uideris stellas. IN festiuitate Sancti Michaelis Archangeli [Sept. 29] similiter contra orientem spectans - ad dexteram partem de uia secede. Et ubi eosdem geminos quasi super scripturam altaris ${ }^{2}$ Sancti ANIaNi uideris tunc horam surgendi scito esse.

Porro in sollempnitate Sancti Hieronimi [Sept. 30] et in Sancti Remigii [Oct. I] ubi ipsas stellas inter | secundam \& terciam dormitorii [23 a] uideris fenestram sic tamen ut propiores uideantur esse secundę fenestrę quam tercię. IN apostolorum Simonis et Iude - natalicio [Oct. 28] ad austrum spectans $\cdot$ dum signum Orionis quasi super tectum armarii quod est inter dormitorium et refectorium uideris - ita tamen ut proxumus ${ }^{8}$ primę refectorii fenestrę uideatur. IN sollempnitate Omnium Sanctorum [Nov. I] ad orientem conuertere. / et dum contra spatium quod est [23 b] inter primam \& secundam dormitorii fenestram capita uideris geminorum ad accendendas lucernas te prepara \& post hęc omnia sona signa. IN Sancti clementis [Nov. 23] dum signum orionis inter terciam \& quartam refectorii fenestram uideris ita tamen ut gladius et uagina te uideri possit simul tunc prepara te at excitandos Fratres.

1 inlcia' for in P Pcia'.

2 It was a custom to inscribe over the altar the name of the saint in whose honour it was erected. References to this practice occur in B. Albers's Consuetudines Monasticae i p. 183 and Wilkins's Concilia i pp. 169,624 .

suicinius is written under proxumus, but is not erased. 